\title{
A Novel Method to Limit the Adverse Effect of Fine Serpentine on the Flotation of Pyrite
}

\author{
Dezhi Liu ${ }^{1}$, Guofan Zhang ${ }^{1,2, *}$, Yanfei Chen ${ }^{1}$, Wei Chen ${ }^{3}$ and Yawen Gao ${ }^{1}$ \\ 1 School of Mineral Processing and Bioengineering, Central South University, Changsha 410083, China; \\ 185601037@csu.edu.cn (D.L.); yanfeichen@csu.edu.cn (Y.C.); gaoyawencsu@163.com (Y.G.) \\ 2 Key Laboratory of Hunan Province for Clean and Efficient Utilization of Strategic Calcium-containing \\ Mineral Resources, Central South University, Changsha 410083, China \\ 3 College of Materials and Mineral Resources, Xi'an University of Architecture and Technology, \\ Xi'an 710055, China; csuchenwei@csu.edu.cn \\ * Correspondence: 155611069@csu.edu.cn; Tel.: +86-139-7510-9810
}

Received: 7 November 2018; Accepted: 6 December 2018; Published: 10 December 2018

\begin{abstract}
A novel method to limit the adverse effect of fine serpentine on the flotation of pyrite was investigated in this paper. The flotation results showed that coarser serpentine possessed a weaker depression effect on the pyrite flotation process, and the use of $\mathrm{KAl}\left(\mathrm{SO}_{4}\right)_{2} \cdot 12 \mathrm{H}_{2} \mathrm{O}$ could efficiently limit the detrimental effect of fine serpentine on pyrite with a maximum increase of pyrite recovery from $14 \%$ to $86 \%$ at $\mathrm{pH}$ 9.0. The results of particle size measurements and rheological measurements exhibited that the addition of $\mathrm{KAl}\left(\mathrm{SO}_{4}\right)_{2} \cdot 12 \mathrm{H}_{2} \mathrm{O}$ increased the particle size of serpentine buta hrdly affected the particle size of pyrite, then limited the formation of serpentine-pyrite aggregates. Adsorption test results showed that the adsorption density of potassium butyl xanthate (PBX) onto pyrite regained with the addition of $\mathrm{KAl}\left(\mathrm{SO}_{4}\right)_{2} \cdot 12 \mathrm{H}_{2} \mathrm{O}$, thereby achieving good flotation improvement. It can be concluded that $\mathrm{KAl}\left(\mathrm{SO}_{4}\right)_{2} \cdot 12 \mathrm{H}_{2} \mathrm{O}$ is likely to be an effective pyrite flotation reagent, especially in the presence of fine serpentine.
\end{abstract}

Keywords: pyrite; fine serpentine; aluminum potassium sulfate dodecahydrate; flotation separation; particle size

\section{Introduction}

Serpentine, as a typical magnesium silicate, often associates with many sulfide ore deposits [1]. Plenty of studies have demonstrated that serpentine can adsorb on the surface of sulfide minerals as "slime coatings" through electrostatic attraction in the flotation process of sulfide ores [2-4]. The coatings of serpentine can reduce the adsorption of collectors and increase the hydrophilicity of valuable minerals $[5,6]$.

In order to eliminate the adverse influence of serpentine on sulfide minerals flotation, chemical additives such as sodium silicate, sodium hexametaphosphate, carboxymethyl cellulose (CMC), and N-carboxymethyl chitosan have been used to prevent the formation of "slime coatings" on valuable mineral surfaces by changing the surface potential of serpentine [7-10]. However, in practice, the results are not so satisfactory due to the high dosage and the lack of selectivity of the dispersant. In addition, physical methods such as ultrasonic treatment and high-intensity conditioning have been usually employed to remove the slime coatings from valuable mineral surfaces [11-13]. However, it appears that ultrasonic treatment and high-intensity conditioning are not efficiently economical methods.

Previous studies have shown that the formation of slime coatings on sulfide mineral surfaces is closely related to the particle size of serpentine: Finer serpentine obtained a greater depressant effect on the flotation of sulphide minerals [14]. Thus, changing the apparent particle size of fine serpentine by adding coagulants may be a possible method to improve the flotation performance of sulfide minerals. 
Aluminum potassium sulfate dodecahydrate $\left(\mathrm{KAl}\left(\mathrm{SO}_{4}\right)_{2} \cdot 12 \mathrm{H}_{2} \mathrm{O}\right)$, which is commonly known as potassium alum, has been most commonly used as an inorganic coagulant for decades due to its characteristics of nontoxicity, cheapness, and wide sources $[15,16] . \mathrm{KAl}\left(\mathrm{SO}_{4}\right)_{2} \cdot 12 \mathrm{H}_{2} \mathrm{O}$ hydrolyzes to form an amorphous floc of $\mathrm{Al}(\mathrm{OH})_{3}(\mathrm{~s})$ to coagulate small particles into large flocs by its high adsorption affinity in aqueous solution $[17,18]$. However, the utilization of $\mathrm{KAl}\left(\mathrm{SO}_{4}\right)_{2} \cdot 12 \mathrm{H}_{2} \mathrm{O}$ to remove the depressant of fine serpentine on the flotation of sulphide minerals has not been studied previously, and thus it was chosen as a potential coagulant in removing slime coatings of fine serpentine from sulphide minerals in this study. Pyrite is the most widespread and abundant of naturally occurring metal sulphides, and is always associated with magnesium silicate minerals $[19,20]$. Therefore, it was chosen as the valuable mineral in this paper. The effect of $\mathrm{KAl}\left(\mathrm{SO}_{4}\right)_{2} \cdot 12 \mathrm{H}_{2} \mathrm{O}$ on the flotation process was evaluated through single mineral flotation, particle size measurements, rheology measurements, and adsorption measurements.

\section{Materials and Methods}

\subsection{Samples and Reagents}

The serpentine and pyrite minerals used for all the experiments were obtained from Donghai, Jiangsu Province, and Yunfu, Guangdong Province of China, respectively. Serpentine and pyrite samples were crushed to $-1 \mathrm{~mm}$ in a laboratory roll crusher and grounded using an agate mortar and pestle to the designed fraction. Here, $-150+74 \mu \mathrm{m},-74+38 \mu \mathrm{m}$, and $-10 \mu \mathrm{m}$ serpentine and $-150+74 \mu \mathrm{m}$ pyrite particles were used for the flotation tests; the $-10 \mu \mathrm{m}$ serpentine and $-150+74 \mu \mathrm{m}$ pyrite particles were used for particle size measurements and rheology measurements; and the $-10 \mu \mathrm{m}$ serpentine and $-38 \mu \mathrm{m}$ pyrite particles were used for the adsorption measurements. According to the results of X-ray diffraction (XRD), shown in Figure 1, the serpentine sample constituted $98 \%$ serpentine and $2 \%$ chlorite, and the purity of pyrite was higher than $98 \%$.

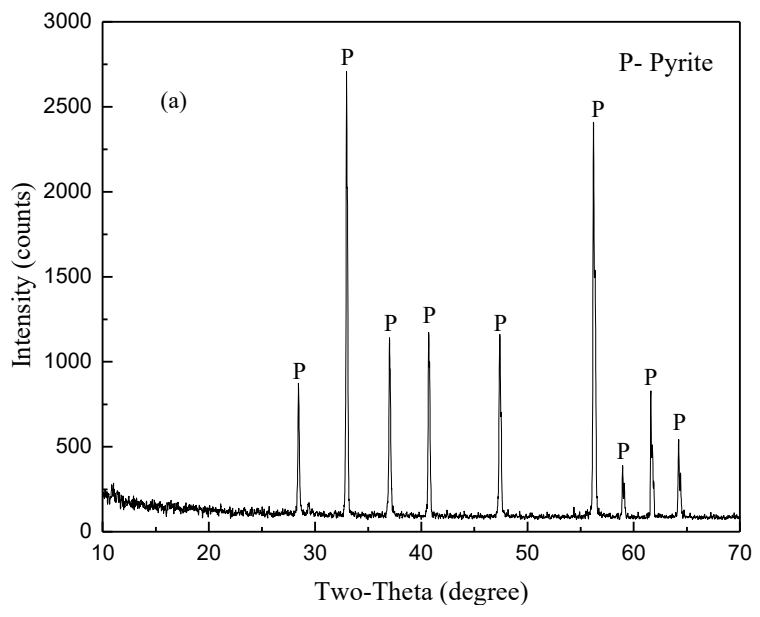

(a)

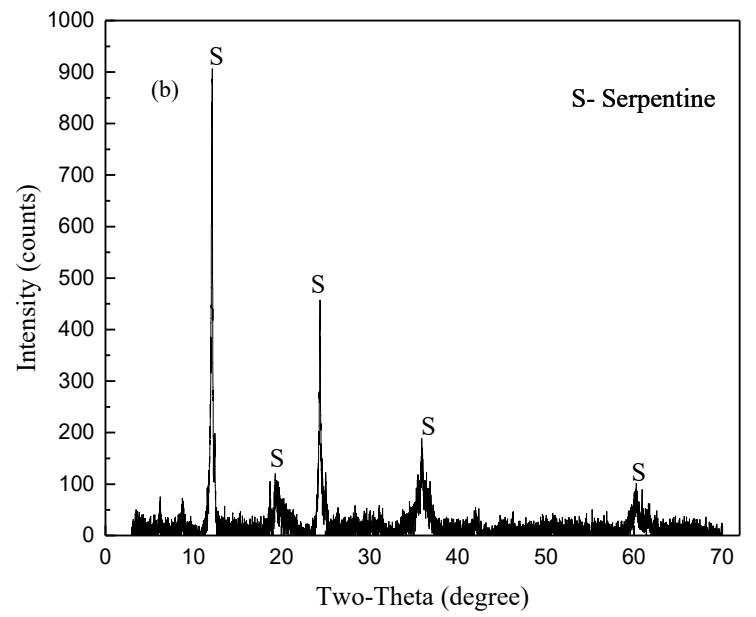

(b)

Figure 1. XRD patterns of the (a) pyrite and (b) serpentine.

Potassium butyl xanthate (PBX, purchased from Macklin Biochemical Co., Ltd., Shanghai, China) with $98 \%$ purity and methyl isobutyl carbinol (MIBC, obtained from Tianzhuo Flotation Reagent Co., Ltd., JiAn, Jiangxi, China) were used as the collector and frother, respectively. The coagulant of $\mathrm{KAl}\left(\mathrm{SO}_{4}\right)_{2} \cdot 12 \mathrm{H}_{2} \mathrm{O}$ with $99.5 \%$ purity was obtained from Fuchen Chemical Reagents Factory, Tianjin, China. Hydrochloric acid $(\mathrm{HCl})$ and sodium hydroxide $(\mathrm{NaOH})$ were used as $\mathrm{pH}$ regulators, and both of them were obtained from Zhuzhou Flotation Reagent Co., Ltd., Hunan province of China. All of the above reagents were of analytical grade, and deionized water with a resistivity of $18.2 \mathrm{M} \Omega \cdot \mathrm{cm}$ at $25^{\circ} \mathrm{C}$ obtained from a Laboratory Water Purification System (Smart-s15, Hitech Instruments Co., Ltd., Shanghai, China) was used for all the experiments. 


\subsection{Flotation}

The single mineral flotation was carried out in an XFG-type mechanical agitation flotation machine with a $40 \mathrm{~mL}$ cell [21]. The pyrite suspension was prepared by adding $2.0 \mathrm{~g}$ of pyrites, which was treated by $5 \mathrm{~min}$ ultrasonic pretreatment to $35 \mathrm{~mL}$ solutions. When needed, $0.2 \mathrm{~g}$ serpentine was added at the beginning of the conditioning period. The $\mathrm{pH}$ regulator, $\mathrm{KAl}\left(\mathrm{SO}_{4}\right)_{2} \cdot 12 \mathrm{H}_{2} \mathrm{O}$, and collector were added into the pulp in sequence, and a 3 min conditioning period was conducted for each reagent. Then frother was added to the pulp and conditioned for $1 \mathrm{~min}$ before the commencement of flotation, and the flotation process was conducted for $3 \mathrm{~min}$. Following this, the concentrates and tailings were collected, filtered, dried, and weighed, and the flotation recovery was calculated based on solid weight distributions between the two products. Each microflotation test was duplicated three times, and the average value and the standard deviation bar were presented in the results of flotation tests.

\subsection{Particle Size Measurements}

Particle size measurements were carried out in a Malvern Mastersizer 2000 (Malvern Instruments Ltd., England) by light scattering. The pulp samples for measurements were prepared by adding $\mathrm{pH}$ regulator, $\mathrm{KAl}\left(\mathrm{SO}_{4}\right)_{2} \cdot 12 \mathrm{H}_{2} \mathrm{O}$. Each pulp sample as wsubsampled twice, the particle size distribution of each pulp sample was measured three times, and the average of six resulting measurements was used for a particle size distribution curve.

The apparent size of serpentine and pyrite samples that were added with a certain amount of $\mathrm{KAl}\left(\mathrm{SO}_{4}\right)_{2} \cdot 12 \mathrm{H}_{2} \mathrm{O}$ were evaluated by the particle size distribution $D_{50}$ (value of the particle diameter at $50 \%$ of the sample volume that existed) and particle size distribution $D_{90}$ (value of the particle diameter at $90 \%$ of the sample volume that existed), which were directly offered by a Mastersizer instrument [22].

\subsection{Rheology Measurements}

The rheological properties of flotation pulp were measured in apparent viscosity by control shear rate $\left(0-400 \mathrm{~s}^{-1}\right)$ mode, whereas the shear yield stress was measured by control shear stress (0.02-20 Pa) mode. For each rheology test, $40 \mathrm{~mL}$ of slurry sample with a designed concentration was prepared in an agitating flotation cell. Then the $\mathrm{pH}$ regulator and $\mathrm{KAl}\left(\mathrm{SO}_{4}\right)_{2} \cdot 12 \mathrm{H}_{2} \mathrm{O}$ were added in sequence as a flotation scheme, and $3 \mathrm{~min}$ of conditioning was conducted before adding the next reagent. The pulp prepared was poured into a sample cup for rheology measurements. Rheological measurements were conducted in an Anton Paar MCR102 rheometer (Anton Paar, Shanghai, China) with a vane impeller probe. A $38 \mathrm{~cm}^{3}$ sample cup (diameter $=27 \mathrm{~mm}$ ) and an impeller (diameter $=24 \mathrm{~mm}$ ) with six outer blades were used. All rheological measurements were performed at an ambient temperature of around $25^{\circ} \mathrm{C}$.

\subsection{Adsorption Measurements}

For adsorption measurements, $1 \mathrm{~g}$ of pyrite powder was added into the PBX solution with a desired concentration in the presence and absence of serpentine in a $250 \mathrm{~mL}$ Erlenmeyer flask. When needed, $\mathrm{KAl}\left(\mathrm{SO}_{4}\right)_{2} \cdot 12 \mathrm{H}_{2} \mathrm{O}$ was added into the mixed pyrite and serpentine suspension. The total volume of the suspension was $100 \mathrm{~mL}$, and the pulp $\mathrm{pH}$ was adjusted to a desired value by adding $\mathrm{NaOH}$ and $\mathrm{HCl}$. Then the suspension was conditioned for $30 \mathrm{~min}$, ensuring that the adsorption process reached equilibrium. After that, the suspensions were centrifuged and filtered, and the filter liquor was collected for adsorption measurements. The adsorption measurements were conducted on a UV-2001 ultraviolet spectrophotometer (Rayleigh, Beijing, China) with the absorbance at $300 \mathrm{~nm}$. The amount of PBX adsorbed on pyrite was calculated though the PBX initial concentration $\left(C_{0}\right)$ and residual concentration $\left(C_{1}\right)$, and the computational formula was shown as:

$$
\varepsilon=\frac{C_{0}-C_{1}}{C_{0}} \times 100 \%
$$




\section{Results and Discussions}

\subsection{Flotation}

Single mineral flotation experiments were first conducted to evaluate the effect of the particle size of serpentine and $\mathrm{KAl}\left(\mathrm{SO}_{4}\right)_{2} \cdot 12 \mathrm{H}_{2} \mathrm{O}$ on the flotation process of the pyrite-serpentine system.

Figure 2 exhibits the effect of serpentine with different particle sizes on the flotation of pyrite as a function of pulp pH. It is evident from Figure 2 that at $\mathrm{pH} 3-9, \mathrm{PBX}$ had excellent collecting ability for bare pyrite. When above $\mathrm{pH} 9$, the flotation recovery of pyrite decreased due to the formation of $\mathrm{Fe}(\mathrm{OH})_{3}$ species on the pyrite surface $[19,23]$. Compared to the flotation recovery of bare pyrite, the pyrite recovery decreased in the presence of serpentine due to the formation of serpentine slimes onto pyrite. It also can be seen that the flotation recovery of pyrite was related to the particle size of serpentine. The finer the serpentine was, the lower the flotation recovery of pyrite was. The results shown in Figure 2 are consistent with previous studies by Feng and Li [14,24].

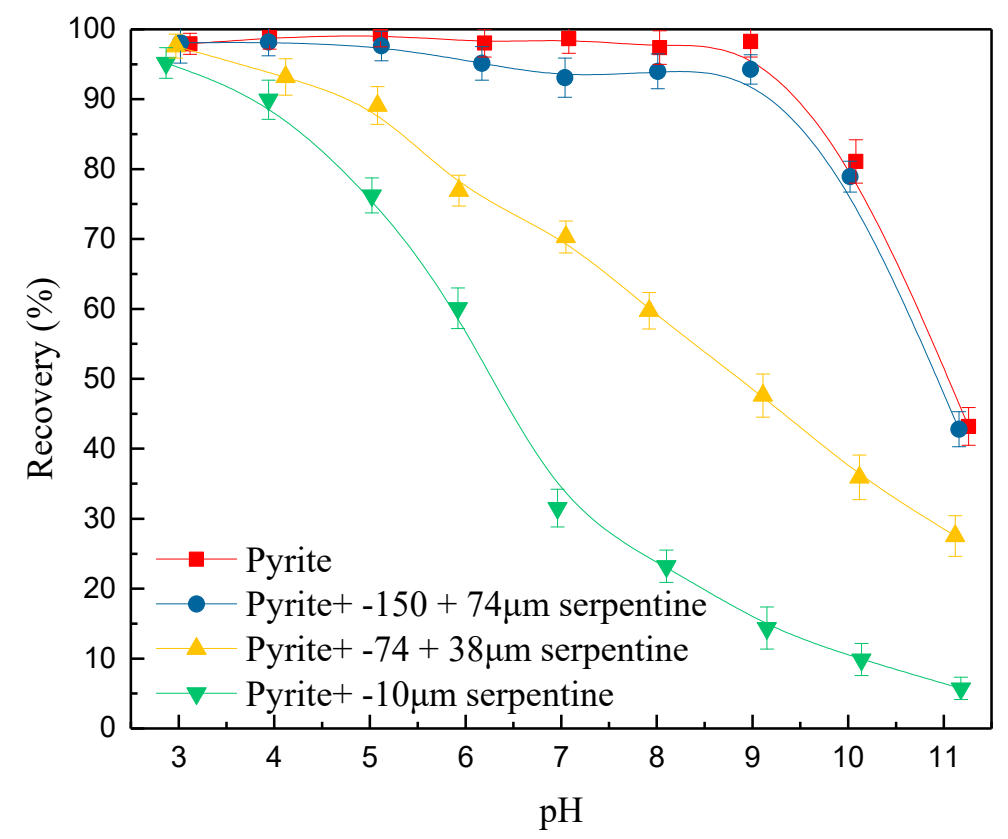

Figure 2. Effect of serpentine with different particle sizes on the flotation of pyrite as a function of pulp $\mathrm{pH}$ (potassium butyl xanthate $[\mathrm{PBX}]=3.75 \times 10^{-5} \mathrm{~mol} / \mathrm{L}$, methyl isobutyl carbinol $[\mathrm{MIBC}]=2 \times 10^{-4} \mathrm{~mol} / \mathrm{L}$ ).

Figure 3 shows the flotation recovery of pyrite as a function of the concentration of $\mathrm{KAl}\left(\mathrm{SO}_{4}\right)_{2} \cdot 12 \mathrm{H}_{2} \mathrm{O}$ in the presence and absence of $-10 \mu \mathrm{m}$ serpentine at $\mathrm{pH} 9.0$. It is obvious that the flotation recovery of pyrite slightly decreased with the increase of $\mathrm{KAl}\left(\mathrm{SO}_{4}\right)_{2} \cdot 12 \mathrm{H}_{2} \mathrm{O}$ concentration without serpentine. A maximum decrease was obtained with the pyrite flotation recovery of $87 \%$

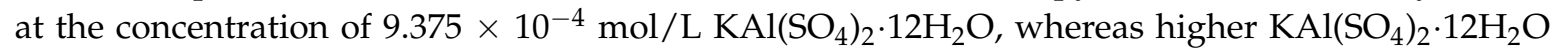
concentration did not further reduce the flotation recovery of pyrite. James et al. [25] proposed the view that metal ions could adsorb on minerals surface via forming metal hydroxide precipitation, because the solubility product of metal hydroxide at the interface is less than the solubility product in the solution, and the concentration of metal ions in the interface area is much higher than that of metal ions in the solution phase. Thus, it can be deduced that the slight decrease of pyrite recovery was caused by the adsorption of aluminum hydroxyl onto pyrite surfaces, which decreased the hydrophobicity of pyrite $[25,26]$. In contrast, the flotation recovery of pyrite was rather low, with a value of about $14 \%$ in the presence of serpentine at $\mathrm{pH}$, which shows that fine serpentine had an adverse influence on pyrite flotation due to the serpentine slime coatings [13]. Interestingly, the flotation recovery of pyrite was significantly improved with the addition of $\mathrm{KAl}\left(\mathrm{SO}_{4}\right)_{2} \cdot 12 \mathrm{H}_{2} \mathrm{O}$, and a maximum increasement 
of pyrite recovery from $14 \%$ to $86 \%$ was obtained with $2.5 \times 10^{-3} \mathrm{~mol} / \mathrm{L} \mathrm{KAl}\left(\mathrm{SO}_{4}\right)_{2} \cdot 12 \mathrm{H}_{2} \mathrm{O}$ in the presence of serpentine.

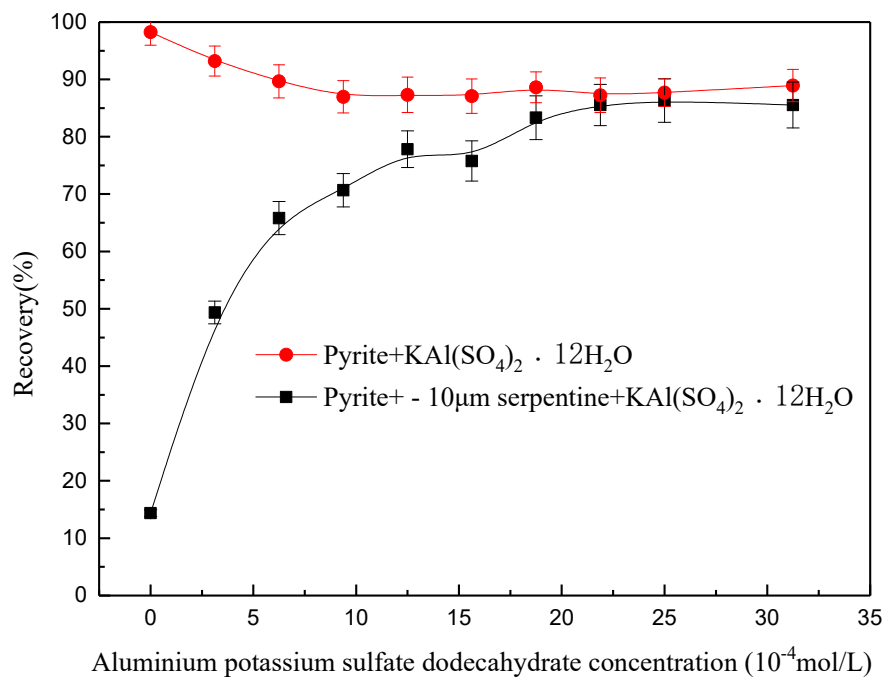

Figure 3. Flotation recovery of pyrite as a function of $\mathrm{KAl}\left(\mathrm{SO}_{4}\right)_{2} \cdot 12 \mathrm{H}_{2} \mathrm{O}$ concentration $\left([\mathrm{PBX}]=3.75 \times 10^{-5} \mathrm{~mol} / \mathrm{L},[\mathrm{MIBC}]=2 \times 10^{-4} \mathrm{~mol} / \mathrm{L}, \mathrm{pH}=9.0\right)$.

Figure 4 shows the flotation recovery of pyrite under different conditions as a function of the pulp $\mathrm{pH}$. It is evident that the adverse effect of serpentine on the flotation of pyrite was related to pulp $\mathrm{pH}$. With the increase of pulp $\mathrm{pH}$, the depression effect decreased. According to previous reports $[9,27]$, the decrease of the depression effect of serpentine was caused by the change of the surface charges of minerals. Besides, it also can be seen that the depression effect of serpentine on pyrite was limited with the addition of $2.5 \times 10^{-3} \mathrm{~mol} / \mathrm{L} \mathrm{KAl}\left(\mathrm{SO}_{4}\right)_{2} \cdot 12 \mathrm{H}_{2} \mathrm{O}$. At pulp pH 5-9, the recovery of pyrite almost reached $90 \%$. However, when pulp pH was below 5 , the elimination effect of $\mathrm{KAl}\left(\mathrm{SO}_{4}\right)_{2} \cdot 12 \mathrm{H}_{2} \mathrm{O}$ on serpentine slimes decreased, which may have been caused by the restriction of the formation of $\mathrm{Al}(\mathrm{OH})_{3}$, which requires a $\mathrm{pH}$ above 4.3 [28].

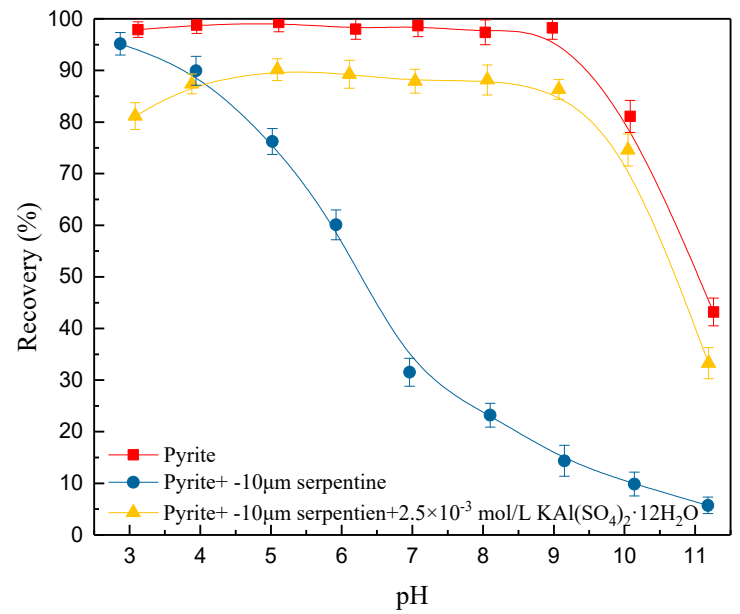

Figure 4. Flotation recovery of pyrite as a function of pulp $\mathrm{pH}\left([\mathrm{PBX}]=3.75 \times 10^{-5} \mathrm{~mol} / \mathrm{L}\right.$, $\left.[\mathrm{MIBC}]=2 \times 10^{-4} \mathrm{~mol} / \mathrm{L},\left[\mathrm{KAl}\left(\mathrm{SO}_{4}\right)_{2} \cdot 12 \mathrm{H}_{2} \mathrm{O}\right]=2.5 \times 10^{-3} \mathrm{~mol} / \mathrm{L}\right)$.

\subsection{Particle Size Measurements}

As a coagulant, the addition of $\mathrm{KAl}\left(\mathrm{SO}_{4}\right)_{2} \cdot 12 \mathrm{H}_{2} \mathrm{O}$ brought an influence on the coagulation behavior of mineral particles, and this may also have been the main reason for the regain of pyrite recovery. In order to investigate the coagulation of mineral particles at different concentrations 
of $\mathrm{KAl}\left(\mathrm{SO}_{4}\right)_{2} \cdot 12 \mathrm{H}_{2} \mathrm{O}$ in the flotation process, particle size measurements were subsequently carried out, and the results are shown in Figures 5 and 6. Figure 5 shows the changes of the particle size distribution of pyrite particles in the absence and presence of $\mathrm{KAl}\left(\mathrm{SO}_{4}\right)_{2} \cdot 12 \mathrm{H}_{2} \mathrm{O}$. The average particle size barely changed (from $153,799 \mu \mathrm{m}$ to $148,254 \mu \mathrm{m}$ ) as $2.5 \times 10^{-3} \mathrm{~mol} / \mathrm{L} \mathrm{KAl}\left(\mathrm{SO}_{4}\right)_{2} \cdot 12 \mathrm{H}_{2} \mathrm{O}$ was added, indicating that $\mathrm{KAl}\left(\mathrm{SO}_{4}\right)_{2} \cdot 12 \mathrm{H}_{2} \mathrm{O}$ could not coagulate pyrite particles.

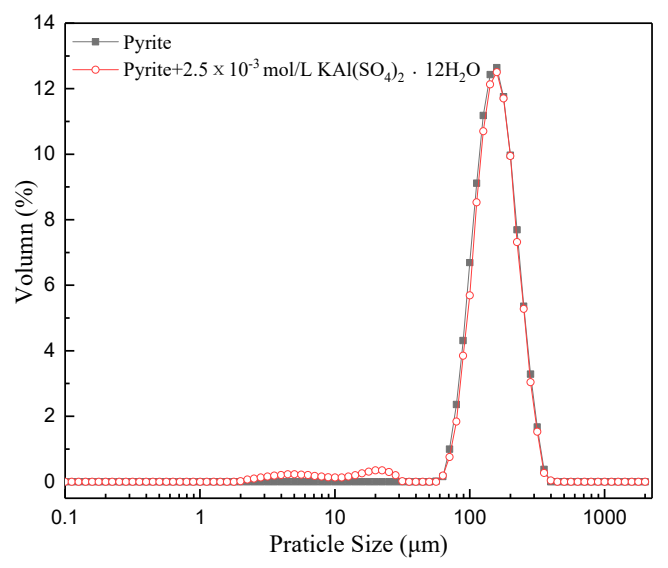

Figure 5. Effect of the presence and absence of $\mathrm{KAl}\left(\mathrm{SO}_{4}\right)_{2} \cdot 12 \mathrm{H}_{2} \mathrm{O}$ on the particle size distribution of pyrite $(\mathrm{pH}=9.0)$.

Figure 6 exhibits the changes in the apparent size of serpentine particles under different concentrations of $\mathrm{KAl}\left(\mathrm{SO}_{4}\right)_{2} \cdot 12 \mathrm{H}_{2} \mathrm{O}$. It can be seen that significant changes in particle size of serpentine particles occurred with the addition of different concentrations of $\mathrm{KAl}\left(\mathrm{SO}_{4}\right)_{2} \cdot 12 \mathrm{H}_{2} \mathrm{O}$. The $D_{50}$ and $D_{90}$ of serpentine particles were $4401 \mu \mathrm{m}$ and $9836 \mu \mathrm{m}$, respectively, in the absence of $\mathrm{KAl}\left(\mathrm{SO}_{4}\right)_{2} \cdot 12 \mathrm{H}_{2} \mathrm{O}$. When the concentration of $\mathrm{KAl}\left(\mathrm{SO}_{4}\right)_{2} \cdot 12 \mathrm{H}_{2} \mathrm{O}$ increased, the dominant peak of fine size fractions decreased, and new peaks generated in the coarse size fractions range. The $D_{90}$ of serpentine particles increased from $9836 \mu \mathrm{m}$ to $304,532 \mu \mathrm{m}$, and the $D_{50}$ increased from $4.401 \mu \mathrm{m}$ to $6.178 \mu \mathrm{m}$, as the concentration of $\mathrm{KAl}\left(\mathrm{SO}_{4}\right)_{2} \cdot 12 \mathrm{H}_{2} \mathrm{O}$ increased from 0 to $2.5 \times 10^{-3} \mathrm{~mol} / \mathrm{L}$. When the concentration of $\mathrm{KAl}\left(\mathrm{SO}_{4}\right)_{2} \cdot 12 \mathrm{H}_{2} \mathrm{O}$ continued to increase, the $D_{90}$ and $D_{50}$ of serpentine particles remained stabilized, corresponding to the variation tendency of flotation results, which are shown in Figure 3.

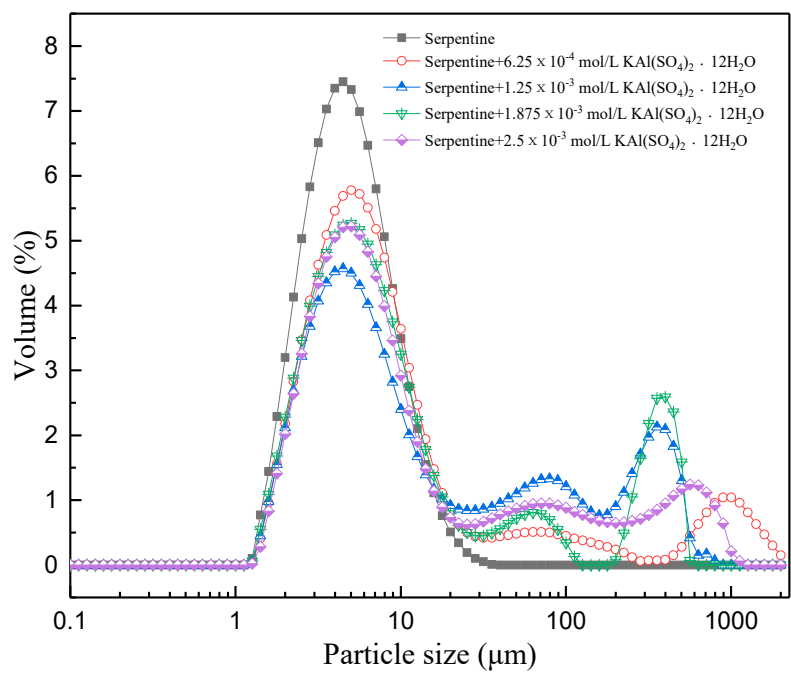

Figure 6. Effect of the presence and absence of $\mathrm{KAl}\left(\mathrm{SO}_{4}\right)_{2} \cdot 12 \mathrm{H}_{2} \mathrm{O}$ on the particle size distribution of serpentine $(\mathrm{pH}=9.0)$. 
The difference of the changes of apparent particle size between pyrite and serpentine may have been caused by the distinction between the particle size fraction of two minerals. Beyond that, the bridge connection between serpentine slimes and $\mathrm{Al}(\mathrm{OH})_{3}(\mathrm{~s})$ by hydroxyl also played an important role [29].

\subsection{Rheological Measurements}

Pulp rheology, which provides much information about the heterocoagulation between particles, has been extensively used to investigate the particle interactions in slurries of fluorite and quartz, galena, and clay minerals [30-32]. In order to investigate the influence caused by serpentine and $\mathrm{KAl}\left(\mathrm{SO}_{4}\right)_{2} \cdot 12 \mathrm{H}_{2} \mathrm{O}$ on single pyrite pulp, rheological tests were conducted by adding serpentine and $\mathrm{KAl}\left(\mathrm{SO}_{4}\right)_{2} \cdot 12 \mathrm{H}_{2} \mathrm{O}$ under different conditions. In Figure $7 \mathrm{a}$, there are obvious changes in apparent viscosity values at certain shear rates after the serpentine was added at relatively low concentrations ( $3 \mathrm{wt} \%$ and $8 \mathrm{wt} \%$ ), which means that there was some mutual interaction between these mixed minerals [33]. As a result, the separation of pyrite and serpentine became difficult, thereby deteriorating the flotation, the same result as in Figure 2. In contrast, the coagulant $\mathrm{KAl}\left(\mathrm{SO}_{4}\right)_{2} \cdot 12 \mathrm{H}_{2} \mathrm{O}$ brought about a slight decrease in the influence on pulp viscosity. Figure $7 \mathrm{~b}$ shows the shear yield point in the same conditions. It concludes that the raised amount of serpentine could significantly increase the shear yield point of mixed pulp. For example, the shear yield stress was as high as $0.57 \mathrm{~Pa}$ when the mass concentration of serpentine reached $8 \mathrm{wt} \%$. Ancey and Jorrot [34] also found that the yield stress sharply increased and approached an infinity value when the solid density reached its maximum value. The increase of shear yield stress with the addition of serpentine indicates that the serpentine-pyrite aggregates were much more difficult to break than single pyrite. However, a maximum decrease of shear yield stress from 0.57 Pa to 0.14 Pa was obtained with the addition of $0.025 \mathrm{~mol} / \mathrm{L} \mathrm{KAl}\left(\mathrm{SO}_{4}\right)_{2} \cdot 12 \mathrm{H}_{2} \mathrm{O}$, suggesting that the addition of $\mathrm{KAl}\left(\mathrm{SO}_{4}\right)_{2} \cdot 12 \mathrm{H}_{2} \mathrm{O}$ could decrease the formation of serpentine-pyrite aggregates.

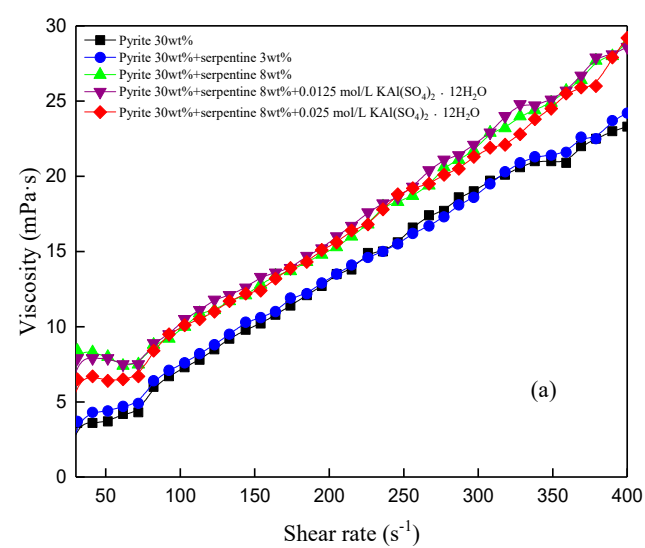

(a)

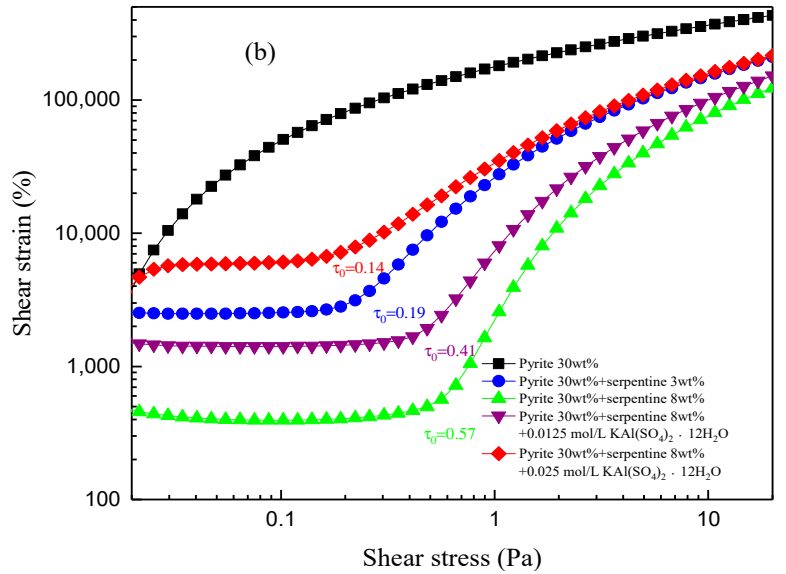

(b)

Figure 7. The (a) apparent viscosity-shear rate curves and (b) the shear strain-shear stress curves of pyrite and serpentine under different conditions $(\mathrm{pH}=9.0)$.

\subsection{Adsorption Measurements}

To further demonstrate the fact that the addition of $\mathrm{KAl}\left(\mathrm{SO}_{4}\right)_{2} \cdot 12 \mathrm{H}_{2} \mathrm{O}$ could coagulate fine serpentine particles and consequently limit the formation of "slimes" on pyrite surface, adsorption measurements were conducted to detect the adsorption density of PBX on mineral surfaces under different conditions. Figure 8 shows the results of adsorption isotherms of PBX onto pyrite and serpentine. The results show that the adsorption density of PBX onto pyrite surface increased with the increase of PBX. However, the adsorption density of PBX onto serpentine surface was always extremely low, illustrating that PBX could not adsorb onto a serpentine surface, which was similar to earlier observations [27]. After the addition of $0.2 \mathrm{~g}$ of serpentine, the adsorption density of PBX 
on pyrite surface decreased significantly, which indicated that the formation of "slimes" consisted of serpentine on the pyrite surface and prevented the adsorption of PBX. This may have been the main reason for the decrease of pyrite recovery in the presence of fine serpentine. With the addition of $2.5 \times 10^{-3} \mathrm{~mol} / \mathrm{L} \mathrm{KAl}\left(\mathrm{SO}_{4}\right)_{2} \cdot 12 \mathrm{H}_{2} \mathrm{O}$, the adsorption density of PBX onto pyrite could be regained, indicating that the fine serpentine slimes were limited effectively.

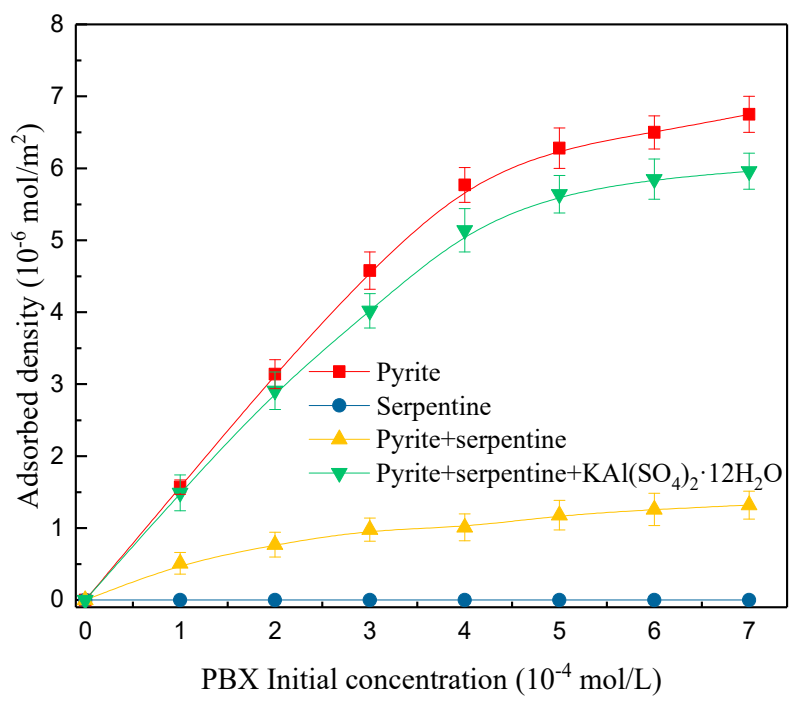

Figure 8. Adsorption isotherms of $\mathrm{PBX}$ on pyrite and serpentine ([serpentine] $=2 \mathrm{~g} / \mathrm{L}$, $\left.\left[\mathrm{KAl}\left(\mathrm{SO}_{4}\right)_{2} \cdot 12 \mathrm{H}_{2} \mathrm{O}\right]=2.5 \times 10^{-3} \mathrm{~mol} / \mathrm{L}, \mathrm{pH}=9.0\right)$.

\section{Mechanism Analysis}

It can be seen obviously from Figures 5 and 6 that the addition of $\mathrm{KAl}\left(\mathrm{SO}_{4}\right)_{2} \cdot 12 \mathrm{H}_{2} \mathrm{O}$ could not

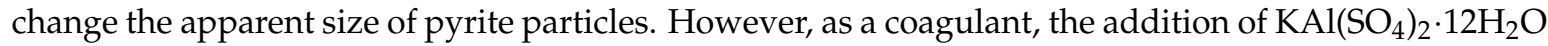
hydrolyzed and formed $\mathrm{Al}(\mathrm{OH})_{3}(\mathrm{~s})$ when pulp $\mathrm{pH}$ was above 4.3 , and they existed as amorphous flocs with strong adsorption capacities $[17,28]$. The amorphous flocs of $\mathrm{Al}(\mathrm{OH})_{3}(\mathrm{~s})$ could adsorb the fine serpentine particles and form flocs, which obtained bigger $D_{90}$ than pyrite did. In the separation process of pyrite and serpentine, the depressant effect of serpentine on pyrite was significantly influenced by the particle size [24]. According to the flotation results shown in Figure 2, finer serpentine particles were easily forming slimes and preventing the adsorption of collectors on pyrite. However, the depressant effect of serpentine decreased as the serpentine particle size increased, which was further confirmed by the flotation results shown in Figures 3 and 4. The results of rheology measurements also indicated that the formation of serpentine-pyrite aggregates was limited with the addition of $\mathrm{KAl}\left(\mathrm{SO}_{4}\right)_{2} \cdot 12 \mathrm{H}_{2} \mathrm{O}$. The results of the adsorption measurements showed that the adsorption density of PBX on pyrite surface was regained in the presence of serpentine, which further confirmed that the formation of serpentine slimes could be limited through increasing the apparent particle size of serpentine with the addition of $\mathrm{KAl}\left(\mathrm{SO}_{4}\right)_{2} \cdot 12 \mathrm{H}_{2} \mathrm{O}$. Therefore, $\mathrm{KAl}\left(\mathrm{SO}_{4}\right)_{2} \cdot 12 \mathrm{H}_{2} \mathrm{O}$ could efficiently eliminate the adverse effect of fine serpentine on the flotation of pyrite.

Based on the abovementioned analysis, the schematic illustration of the effect of $\mathrm{KAl}\left(\mathrm{SO}_{4}\right)_{2} \cdot 12 \mathrm{H}_{2} \mathrm{O}$ in the pyrite-serpentine system is shown in Figure 9. In Figure 9, the serpentine slimes coating was formed on the pyrite surface without $\mathrm{KAl}\left(\mathrm{SO}_{4}\right)_{2} \cdot 12 \mathrm{H}_{2} \mathrm{O}$. With the addition of $\mathrm{KAl}\left(\mathrm{SO}_{4}\right)_{2} \cdot 12 \mathrm{H}_{2} \mathrm{O}$, fine serpentine particles could be coagulated and obtained a bigger apparent particle size. Subsequently, the formation of serpentine slimes onto pyrite was prevented, and the adsorption density of PBX on the surface of pyrite was regained, which was consistent with the results of particle size measurements, rheology measurements, and adsorption measurements. One could explain the result as the use of $\mathrm{KAl}\left(\mathrm{SO}_{4}\right)_{2} \cdot 12 \mathrm{H}_{2} \mathrm{O}$ being able to eliminate the adverse effect of fine serpentine on the flotation process of pyrite. 

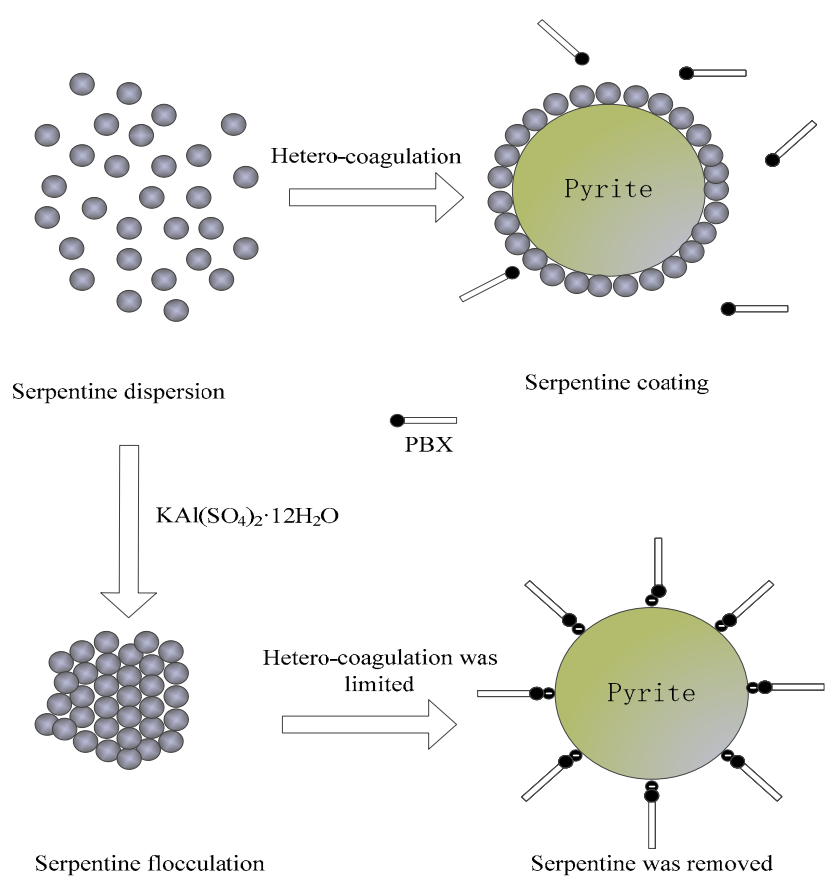

Figure 9. Schematic illustration of the effect of $\mathrm{KAl}\left(\mathrm{SO}_{4}\right)_{2} \cdot 12 \mathrm{H}_{2} \mathrm{O}$ on the flotation of pyrite in the presence of serpentine.

\section{Conclusions}

The use of $\mathrm{KAl}\left(\mathrm{SO}_{4}\right)_{2} \cdot 12 \mathrm{H}_{2} \mathrm{O}$ to limit the adverse effect of fine serpentine in the pyrite flotation process was investigated in this paper. From the results of the flotation tests, particle size measurements, rheology measurements, and adsorption measurements above, conclusions could be reached as follows.

Fine serpentine possessed a strong depressant effect on the flotation of pyrite in the presence of $\mathrm{PBX}$, which could be efficiently solved by the utilization of $\mathrm{KAl}\left(\mathrm{SO}_{4}\right)_{2} \cdot 12 \mathrm{H}_{2} \mathrm{O}$. The results of particle size measurements and rheology measurements showed that the addition of $\mathrm{KAl}\left(\mathrm{SO}_{4}\right)_{2} \cdot 12 \mathrm{H}_{2} \mathrm{O}$ increased the apparent particle size of serpentine remarkably through the flocculation of $\mathrm{Al}(\mathrm{OH})_{3}(\mathrm{~s})$, in contrast, had little influence on the pyrite particle size. Therefore, the formation of serpentine-pyrite aggregates was prevented. The coarser the serpentine particle in the flotation system of pyrite and serpentine, the lesser the depressant effect on pyrite was. The results of adsorption measurements also proved that the adsorption density of $\mathrm{PBX}$ on pyrite regained with the addition of $\mathrm{KAl}\left(\mathrm{SO}_{4}\right)_{2} \cdot 12 \mathrm{H}_{2} \mathrm{O}$. Therefore, $\mathrm{KAl}\left(\mathrm{SO}_{4}\right)_{2} \cdot 12 \mathrm{H}_{2} \mathrm{O}$ is likely to be a reagent of great significance in eliminating the adverse effect of fine serpentine on the pyrite flotation process.

Author Contributions: D.L. designed the experiment and wrote this paper; G.Z. analyzed the data, was involved in the discussion of the results, and approved reading the manuscript; D.L., Y.C., W.C., and Y.G. completed the experiments and recorded the data.

Funding: This work was financially supported by the Major State Basic Research Development Program of China (973 Program), the Innovation Driven Plan of Central South University (Grant No. 2015CX005), the Key Laboratory of Hunan Province for Clean and Efficient Utilization of Strategic Calcium-Containing Mineral Resources (No. 2018TP1002), and the Fundamental Research Funds for the Central Universities of Central South University (project no. 2018zzts791).

Conflicts of Interest: The authors declare no conflict of interest.

\section{References}

1. Basile, A.; Hughes, J.; McFarlane, A.J.; Bhargava, S.K. Development of a model for serpentine quantification in nickel laterite minerals by infrared spectroscopy. Miner. Eng. 2010, 23, 407-412. [CrossRef]

2. Pietrobon, M.C.; Grano, S.R.; Sobieraj, S.; Ralston, J. Recovery mechanisms for pentlandite and MgO-bearing gangue minerals in nickel ores from Western Australia. Miner. Eng. 1997, 10, 775-786. [CrossRef] 
3. Edwards, G.R.; Kipkie, W.B.; Agar, G.E. The effect of slime coatings of the serpentine minerals, chrysotile and lizadite, on pentlandite flotation. Int. J. Miner. Process. 1980, 7, 33-42. [CrossRef]

4. Liu, C.; Ai, G.; Song, S. The effect of amino trimethylene phosphonic acid on the flotation separation of pentlandite fromlizardite. Powder Technol. 2018, 336, 527-532. [CrossRef]

5. Yang, S.; Xie, B.; Lu, Y.; Li, C. Role of magnesium-bearing silicates in the flotation of pyrite in the presence of serpentine slimes. Powder Technol. 2018, 332, 1-7. [CrossRef]

6. Zhou, X.; Feng, B. The effect of polyether on the separation of pentlandite and serpentine. J. Mater. Res. Technol. 2015, 4, 429-433. [CrossRef]

7. Feng, B.; Lu, Y.; Feng, Q.; Li, H. Solution chemistry of sodium silicate and implications for pyrite flotation. Ind. Eng. Chem. Res. 2012, 51, 12089-12094. [CrossRef]

8. Lu, Y.P.; Zhang, M.Q.; Feng, Q.M.; Long, T.; Ou, L.M.; Zhang, G.F. Effect of sodium hexametaphosphate on separation of serpentine from pyrite. Trans. Nonferrous Met. Soc. China 2011, 21, 208-213. (In English) [CrossRef]

9. Bremmell, K.E.; Fornasiero, D.; Ralston, J. Pentlandite-lizardite interactions and implications for their separation by flotation. Colloids Surf. A Physicochem. Eng. Asp. 2005, 252, 207-212. [CrossRef]

10. Zhang, C.; Liu, C.; Feng, Q.; Chen, Y. Utilization of N-carboxymethyl chitosan as selective depressants for serpentine on the flotation of pyrite. Int. J. Miner. Process. 2017, 163, 45-47. [CrossRef]

11. Feng, B.; Feng, Q.; Lu, Y.; Lv, P. The effect of conditioning methods and chain length of xanthate on the flotation of a nickel ore. Miner. Eng. 2012, 39, 48-50. [CrossRef]

12. Chen, G.; Grano, S.; Sobieraj, S.; Ralston, J. Effect of High Intensity Conditioning on the flotation of a nickel ore, Part 2: Mechanisms. Miner. Eng. 1999, 12, 1359-1373. [CrossRef]

13. Yu, Y.; Ma, L.; Cao, M.; Liu, Q. Slime coatings in froth flotation: A review. Miner. Eng. 2017, 114, $26-36$. [CrossRef]

14. Feng, B.; Lu, Y.; Luo, X. The effect of quartz on the flotation of pyrite depressed by serpentine. J. Mater. Res. Technol. 2015, 4, 8-13. [CrossRef]

15. Ødegaard, H.; Fettig, J.; Ratnaweera, H. Coagulation with prepolymerized metal salts. Chem. Water Wastewater Treat. 1990, 304, 189-220. [CrossRef]

16. Udoma, E.J.; Umoh, M.S.; Udosen, E.O. Recto-vaginal fistula following coitus: An aftermath of vaginal douching with aluminium potassium sulphate dodecahydrate (potassium alum). Int. J. Gynecol. Obstet. 1999, 66, 299-300. [CrossRef]

17. Nogaro, G.; Burgin, A.J.; Schoepfer, V.A.; Konkler, M.J.; Bowman, K.L.; Hammerschmidt, C.R. Aluminum sulfate (alum) application interactions with coupled metal and nutrient cycling in a hypereutrophic lake ecosystem. Environ. Pollut. 2013, 176, 267-274. [CrossRef]

18. Hu, C.; Liu, H.; Qu, J.; Wang, D.; Ru, J. Coagulation behavior of aluminum salts in eutrophic water: Significance of Al13species and pH control. Environ. Sci. Technol. 2006, 40, 325-331. [CrossRef]

19. Bicak, O.; Ekmekci, Z.; Bradshaw, D.J.; Harris, P.J. Adsorption of guar gum and CMC on pyrite. Miner. Eng. 2007, 20, 996-1002. [CrossRef]

20. Feng, B.; Feng, Q.; Lu, Y. Dispersion mechanism of CMC on flotation system of serpentine and pyrite. J. Cent. South Univ. (Science and Technology) 2013, 44, 2644-2649. (In Chinese)

21. Chen, Y.; Shi, Q.; Feng, Q.; Lu, Y.; Zhang, W. The Effect of Conditioning on the Flotation of Pyrrhotite in the Presence of Chlorite. Minerals 2017, 7, 125. [CrossRef]

22. Chen, W.; Feng, Q.; Zhang, G.; Li, L.; Jin, S. Effect of energy input on flocculation process and flotation performance of fine scheelite using sodium oleate. Miner. Eng. 2017, 112, 27-35. [CrossRef]

23. Fornasiero, D.; Ralston, J. Iron hydroxide complexes and their influence on the interaction between ethyl xanthate and pyrite. J. Colloid Interface Sci. 1992, 151, 225-235. [CrossRef]

24. LI, Z.; HAN, Y.; LI, Y.; Gao, P. Effect of serpentine and sodium hexametaphosphate on ascharite flotation. Trans. Nonferrous Met. Soc. China 2017, 27, 1841-1848. (In English) [CrossRef]

25. James, R.O.; Healy, T.W. Adsorption of hydrolyzable metal ions at the oxide-water interface. II. Charge reversal of $\mathrm{SiO}_{2}$ and $\mathrm{TiO}_{2}$ colloids by adsorbed $\mathrm{Co}(\mathrm{II}), \mathrm{La}(\mathrm{III})$, and $\mathrm{Th}(\mathrm{IV})$ as model systems. J. Colloid Interface Sci. 1972, 40, 53-64. [CrossRef]

26. Yin, W.; Sun, C. Review on Research Status on Flotation Principles of Silicate Minerals. Conserv. Util. Miner. Resour. 2001, 3, 17-22. 
27. Feng, B.; Feng, Q.; Lu, Y. The effect of lizardite surface characteristics on pyrite flotation. Appl. Surf. Sci. 2012, 259, 153-158. [CrossRef]

28. Somasundaran, P.; Dianzuo, W. Solution Chemistry: Minerals and Reagents; Elsevier: Amsterdam, The Netherlands, 2006.

29. Sun, H.J.; Zhang, W.Z. Study on flocculating effects of three kinds of flocculants. J. Shenyang Univ. Chem. Technol. 2005, 19, 314-317. (In Chinese)

30. Zhang, M.; Peng, Y. Effect of clay minerals on pulp rheology and the flotation of copper and gold minerals. Miner. Eng. 2015, 70, 8-13. [CrossRef]

31. Zhang, G.; Gao, Y.; Chen, W.; Liu, D. The Role of Water Glass in the Flotation Separation of Fine Fluorite from Fine Quartz. Minerals 2017, 7, 157. [CrossRef]

32. Prestidge, C.A. Rheological investigations of galena particle interactions. Colloids Surf. A Physicochem. Eng. Asp. 1997, 126, 75-83. [CrossRef]

33. Ancey, C.; Jorrot, H. Yield stress for particle suspensions within a clay dispersion. J. Rheol. 2001, 45, $297-319$. [CrossRef]

34. Gao, Y.; Zhang, G.; Wang, M.; Liu, D. The Critical Role of Pulp Density on Flotation Separation of Nickel-Copper Sulfide from Fine Serpentine. Minerals 2018, 8, 317. [CrossRef]

(C) 2018 by the authors. Licensee MDPI, Basel, Switzerland. This article is an open access article distributed under the terms and conditions of the Creative Commons Attribution (CC BY) license (http:/ / creativecommons.org/licenses/by/4.0/). 